\title{
The enigma of Helicobacter pylori infection and gastric cancer
}

\author{
Uday C. Ghoshal, \\ Department of Gastroenterology, Sanjay Gandhi Postgraduate Institute of Medical Science, \\ Lucknow 226 014, India
}

Rupesh Chaturvedi, and Division of Gastroenterology, Vanderbilt University Medical Center, 1030C MRB IV 2215 B Garland Ave., Nashville, TN 37232, USA

Pelayo Correa

Division of Gastroenterology, Vanderbilt University Medical Center, 1030C MRB IV 2215 B Garland Ave., Nashville, TN 37232, USA

Pelayo Correa: pelayo.correa@vanderbilt.edu

\section{Abstract}

Although $H$. pylori has been recognized as a class I carcinogen, incongruence between infection prevalence and cancer incidence has been reported. Holcombe called attention to the high prevalence of infection in the face of low cancer rates, which he called "The African Enigma". Similar observations have now been made in other geographic areas. Gastric carcinoma should be considered an infectious disease, for which the classical epidemiologic model of causality applies. The model proposes that tissue injury inflicted by the infectious agent is modulated by its interactions with host and environmental factors. Although approximately half of the world's population is infected, only a small proportion of people develop cancer. The African enigma is a striking example of the major contrasts in cancer risk among populations with similarly high prevalence of infection. The mechanisms involved in reducing the risk of cancer in infected individuals are explored in this article, which may lead to the design of effective prevention strategies.

\section{Introduction}

Marshall and Warren's seminal letters published in The Lancet in 1983 suggesting that gastric cancer could be related to Helicobacter pylori (H. pylori) infection opened an international scientific debate [1]. In 1992, however, Holcombe discussed the incongruence between the geographic distributions of the two entities [2]. He called attention to the "African Enigma "defined as a very high prevalence of infection but low incidence of gastric cancer [2]. Similar "enigmas" have been described in Malaysia, India, China, Colombia and Costa Rica, and is illustrated in Fig. 1 [3-9]. In 1994, the International Agency for Research on Cancer classified H. pylori infection as a Class I carcinogen for humans [10]. Since the infection is generally acquired in infancy or early childhood but invasive carcinoma is usually diagnosed five or more decades later, a prolonged precancerous process takes place. The process has been described as a cascade, and is illustrated in Fig. 2 [11]. It has been estimated that approximately $50 \%$ of the world's population carries $H$. pylori but only a small proportion (approximately one in 2,000 infected subjects per year) develop gastric cancer. The outcome of the infection varies

(C) Indian Society of Gastroenterology 2010

Correspondence to: Pelayo Correa, pelayo. correa@vanderbilt. edu. 
considerably: from mild chronic sub clinical gastritis to peptic ulcer to gastric neoplasia. The almost inescapable conclusion of this scenario is that damage done by the bacteria to the gastric mucosa over decades is modulated by other etiological factors. They may be related to the oncogenic potential of the bacterial strain, the host's response to the infection or to the external environment. The African enigma, therefore, represents modulation of the inflammatory process initiated by the infection, towards a non-neoplastic outcome.

The available scientific evidence supports the role of the following factors, listed in order of their possible importance in explaining the enigma.

1. Oncogenic potential of different bacterial genotypes

2. Modulation of the immune response to Helicobater infection towards a Th2 type

3. Dietary influences, especially the abundance of foods rich in antioxidant micronutrients

4. Genetic susceptibility

The role of each factor will be briefly summarized, followed by a discussion of the evidence for their involvement in each geographic region.

\section{Bacterial Oncogenicity}

Helicobacter pylori are part of the normal biota of approximately $50 \%$ of the world's population. Throughout history, the bacterium has migrated with its human host. Both species apparently originated from Africa some 60,000 years ago. In modern times, typical strains representing geographic areas have been identified as European, African and Asian utilizing multiple locus sequence typing (MLST) of housekeeping genes [12]. The linkage of theses genotypes to cancer risk is not well understood. Most Asian strains are associated with higher cancer risk. African strains might be expected to correlate with the low cancer risk observed in most African populations but no convincing scientific evidence to support this assumption is currently available.

The role of $H$. pylori in determining disease outcome has been addressed. The attention has been focused on loci that increase the risk of disease, which was first recognized with the identification of the pathogenicity island [13-15]. By inference, bacteria without this island are associated with non-neoplastic outcomes. Size variation in the CagA protein has been attributed to the presence of variable numbers of repeat sequences in the $3^{\prime}$ region of the gene. This variation has been linked to severity of disease and development of gastric cancer [16]. Homologous recombination within the $3^{\prime}$ region of cagA causes arrangement of GluPro-Ile-Ala (EPIYA) amino acid containing sequences in numbers and order. Depending on surrounding sequences, the EPIYA motifs have been classified as A, B, C, and D [17]. EPIYA D is only found in Eastern strains and may be associated with high cancer risk. Upon entering cells CagA is phosphorylated on EPIYA motifs by src and abl kinases and initiates diverse biological responses. Recently, Basso et al has shown that an increasing number of EPIYA-C motifs may increase the risk of Gastric cancer [18]. VacA is another H. pylori virulence factor that has been studied in detail as a mediator of cancer risk. Polymorphisms in the signal (s), intermediate (i), and middle (m) region of VacA gene are associated with different disease outcome [19]. Another virulence factor, iceA, also has been shown to affect clinical outcome [20]. H. pylori outer membrane proteins bind to gastric epithelial cells and are essential for colonization and chronic persistence which and affect clinical outcome. The blood group antigen binding adhesin (BabA), and the sialic acid binding adhesin (SabA) have been identified as major outer membrane proteins that bind to Lewis $b$ antigen $\left(\mathrm{Le}^{\mathrm{b}}\right)$ and related sialyl-Lewis $\mathrm{x}$ and sialyl-Lewis a antigens, respectively [21]. Gerhard et al have 
shown that presence of BabA in German clinical isolates positively correlates with gastric adenocarcinoma [22].

Giannakis et al reported that $H$. pylori isolates from the same individual taken 4 years apart during the progression from chronic atrophic gastritis to gastric adenocarcinoma showed microevolution. By mono-association studies in gnotobiotic transgenic mouse model these investigators showed that isolates obtained after the development of carcinoma interacted more intensely with mouse gastric progenitor (stem) epithelial cells. Cancer associated isolates also up regulated metabolic pathways and tumor suppressor genes associated with the development of gastric cancer in humans, in a manner distinct from the atrophic gastritis-associated isolates [23]. This underscores the importance of adaptation of strains and their genetic microevolution during disease progression.

The interaction of $H$. pylori with specific cell types causes diverse biological responses. In epithelial cells, $H$. pylori infection causes rearrangement of the cytoskeleton, trans-activation of EGFR and AP-1 and activation of signaling pathways. These pathways have both proliferative and anti-apoptotic effects. $H$. pylori induces gastric infiltration by neutrophils and macrophages that express inducible nitric oxide synthase (iNOS) that produces nitric oxide, which can be converted to reactive nitrogen species, leading to DNA damage and impairment of DNA repair [24]. H. pylori induces spermine oxidase (SMO) in epithelial cells and macrophages that generates hydrogen peroxide and causes DNA damage [25]. Survival of these damaged cells may lead to accumulation of genetic abnormalities and transformation.

\section{Immune response}

Most reports in humans and experimental animals agree that the immune response to $H$. pylori infection is predominantly pro-inflammatory or Th 1 type. However, in some patients there is clear predominance of a Th 2 type response. The immune response to Helicobacter infection can be modulated in mice by co-infection with nematodes towards a Th2 type that protects against gastric atrophy, a precancerous lesion [26]. Such modulation is mediated by down-regulation of the Th1 cytokines TNF $\alpha$ and IL $1 \beta$, and higher levels of the Th2 cytokines IL 4 and IL 10.

\section{Diet}

The diverse clinical outcomes of $H$. pylori infection may be influenced by dietary habits of the populations under study. It has been consistently shown that diets rich in antioxidants such as fresh fruits and vegetables decrease gastric cancer risk, emphasizing that oxidative stress and chronic inflammation may be one mechanisms by which $H$. pylori induces gastric cancer. Curcumin, an active anti-inflammatory compound in Indian spices, can inhibit NFkB complex activation and IL-8 induction in gastric cells infected with H. pylori [27, 28]. Therefore, this compound may also exert anti-carcinogenic effects. Piperine (a compound from black pepper), and quercetine (a compound found in onion) can increase curcumin bioavailability and its effect. Onion consumption has been associated with lower gastric cancer risk in a Netherlands cohort study [29]. People living in the Indian subcontinent consume these ingredients daily and from a very young age. The possible influence of diet in determining oncogenicity of $\mathrm{H}$. pylori is suggested by recent work demonstrating that high salt concentrations lead to higher expression of CagA [30].

\section{Genetic susceptibility}

Helicobacter pylori infection induces chronic inflammation and expression of a variety of cytokines. Genetic polymorphisms in cytokine-encoding genes may affect the magnitude 
and type of the response. El-Omar et al have shown an association between IL-1 beta gene cluster polymorphism and gastric cancer in patients with $H$. pylori infection. The association is ethnicity-specific: evident in Caucasians but not in Asians [31]. Polymorphisms in tumor necrosis factor- $\alpha$, IL-1, IL-6, IL-8, IL-10, TLR-4, COX-2, glutathione S transferase (GST), Toll-like receptor, man-nose binding lectins and HLA have also been associated with increased risk for gastric cancer, gastric lymphoma and pre-neoplastic lesions [4, 32-35]. The Indian enigma characterized by prevalence of $H$. pylori infection but low frequency of gastric cancer might be related to host response to the bacterium due to genetic factors [36].

It has been shown that genetic susceptibility factors interact with bacterial virulence factors to increase cancer risk. Figueiredo et al have reported odds ratio of 87 for gastric carcinoma for individuals carrying the susceptibility allele IL $1 \beta 511 \mathrm{~T}$, infected with bacteria carrying the Vac A s 1 virulence allele [37]. However, the possible role of genetic susceptibility in explaining the African enigma has not been determined.

\section{The enigma in Africa}

After the original observations by Holcombe, investigators from several geographic areas confirmed high prevalence of the infection in the face of low frequency of gastric cancer [2]. A study in South Africa reported that the majority of isolates were cagA positive, vacA s1m1 genotype. The cag A positive strains had the shortest fragment length in the $3^{\prime}$ end region $[38,39]$.

In sub-Saharan Africa, Mitchell et al. reported that the specific IgG subclass response to $H$. pylori infection is predominantly IgG1, suggestive of a Th2 bias [40]. The IgG1/IgG2 ratio was used to compare patients from Soweto to patients from Germany and Australia. The average ratio for Sowetans was 4.5, approximately 20 times higher than 0.242 for Australians and Germans. This immune modulation may be related to intestinal parasites.

\section{The Asian enigma}

Studies in Asian countries such as Thailand, India, Bangladesh, Pakistan, Iran, Saudi Arabian countries, Israel and Malaysia, have reported high frequency of $H$. pylori infection co-existing with low incidence of gastric cancer. The possibility that less virulent bacteria is more prevalent in populations at low risk while more virulent strains predominate in highrisk Asian populations needs to be investigated more thoroughly. Genotypic analysis of $H$. pylori strains from India showed virulent strains to be present in more than $80 \%$ of adults and children with gastroduodenal diseases and in control population [41]. Most patients with non-ulcer dyspepsia from India have antibodies to CagA in the serum [42]. In one study of 279 patients with gastric neoplasms ( 263 gastric carcinomas and 16 primary gastric lymphomas) and controls (101 non-ulcer dyspepsia and 355 healthy subjects) the frequency of anti-CagA IgG antibody was similar among gastric carcinoma patients and controls, suggesting that differences in virulent factors are unlikely to explain variations in outcome of $H$. pylori infection [3]. Recently, Ahmed et al have reported that most of the H. pylori isolated from patients with diverse cultural, geographic and linguistic background from India are cagA positive and harbor vacA $\mathrm{s} 1 \mathrm{~m} 1$; only $6.3 \%$ of clinical isolates were vacA $\mathrm{s} 2 \mathrm{~m} 1$. This highlights the possibility of other factors modulating the disease outcome in different geographical regions [43].

Dietary habits, especially the abundance of curcumin, could be one explanation for the Indian enigma. In eastern and southern India higher frequency of gastric cancer is observed. Rice is the staple cereal in eastern India. Non-vegetarian foods, particularly fish, are also very common in eastern Indian diet, which is also spicy and contains more salt [5]. Diet in southern India is somewhat similar to that in eastern India with an excess of rice, fish, and 
salt. In contrast, northern Indian diet is mainly wheat-based and a greater proportion of people are vegetarian. These findings suggest that dietary modification, though difficult, may be useful in chemoprevention of $H$. pylori related cancer.

\section{The enigma in Latin America}

Marked contrasts in the incidence of gastric cancer have been reported from Colombia. The inhabitants of the high altitude Andes Mountains have very high rates of gastric cancer, estimated in 1976 to be 150 per 100,000 inhabitants [44]. By contrast, the incidence rate for inhabitants of the coast, at sea level, was 2.8 per 100,000 [45]. In the south of the country, in the state of Nariño, high risk mountains population (Tuquerres) are only approximately 150 Mi apart from coastal low risk populations (Tumaco). The prevalence of $H$. pylori infection is high in both populations: $\sim 50 \%$ at age 2 and over $80 \%$ after age 10 [46]. The relative frequency of virulent strains is shown in Table 1.

Major differences between these populations are also found in the diet: predominantly salty potatoes and beans in the mountains versus fresh fish, vegetables and fruits in the coast [47]. Studies comparing populations at high—versus low-risk for gastric cancer in Colombia have emphasized the predominance of a Th 2 type response in the low risk populations, as shown by the high levels of IgE in the serum and by the predominance of eosinophilic infiltration in the gastric mucosa $[47,48]$. These studies have postulated that in low cancer risk populations, a Th 2 type response, related to the intestinal parasitism, may be protective. In support of this view, the prevalence of intestinal parasitism by helminthes is $50 \%$ in the coast versus $25 \%$ in the mountains

Similar to Colombia, in Costa Rica, incidence rates of gastric cancer for inhabitants of the mountains (30 to 40 per 100,000) are higher than those from the coast ( 7 to 15 per 100,000). The prevalence of $H$. pylori infection is similarly high in both populations (63 to 73\%). However, $79 \%$ of $\mathrm{H}$. pylori isolates were cagA positive in the mountain population, compared to $54 \%$ in the coast.

\section{Epilogue}

The African enigma reflects the interplay of three major etiologic forces: the oncogenic potential of the specific strains of $H$. pylori, the modulation by co-infections of the immune response towards a Th 2 type and the abundance of antioxidant micronutrients in the diet. In the classical epidemiologic model these forces form a web of causation whose dynamics probably differs in the populations where the enigma has been reported. The oncogenic potential of the bacterium plays a prominent role in Latin America. The immune modulation by co-infection, most probably helminthes, plays a prominent role in Africa and in Latin America. The abundance of antioxidant micronutrients appears to be a dominant factor in India. The combined effect of these factors is clear in Latin America but most probably occurs in other populations.

Research on the specific factors that reduce cancer risk in populations where the enigma has been documented has the potential of identifying the mechanisms responsible for the reduced risk. Once identified, intervention measures can be designed to prevent gastric cancer. Prevention is the only hope of controlling this major health burden to humanity.

\section{References}

1. Warren R, Marshall B. Unidentified curved bacilli on gastric epithelium in active chronic gastritis. Lancet. 1983; 1:1273-5. [PubMed: 6134060]

2. Holcombe C. Helicobacter pylori: the African enigma. Gut. 1992; 33:429-31. [PubMed: 1582581] 
3. Ghoshal UC, Tiwari S, Dhingra S, et al. Frequency of Helicobacter pylori and CagA antibody in patients with gastric neoplasms and controls: the Indian enigma. Dig Dis Sci. 2008; 53:1215-22. [PubMed: 18351464]

4. Achyut BR, Tripathi P, Ghoshal UC, Moorchung N, Mittal B. Interleukin-10 (-819 C/T) and tumor necrosis factor-alpha (-308 G/A) gene variants influence gastritis and lymphoid follicle development. Dig Dis Sci. 2008; 53:622-9. [PubMed: 17717744]

5. Singh K, Ghoshal UC. Causal role of Helicobacter pylori infection in gastric cancer: an Asian enigma. World J Gastroenterol. 2006; 12:1346-51. [PubMed: 16552799]

6. Goh KL, Cheah PL, Md N, Quek KF, Parasakthi N. Ethnicity and H. Pylori as risk factors for gastric cancer in malaysia: a prospective case control study. Am J Gastroenterol. 2007; 102:40-5. [PubMed: 17100981]

7. Bravo LE, van Doom LJ, Realpe JL, Correa P. Virulence-associated genotypes of Helicobacter pylori: do they explain the African enigma? Am J Gastroenterol. 2002; 97:2839-42. [PubMed: 12425557]

8. Con SA, Valerin AL, Takeuchi H, et al. Helicobacter pylori CagA status associated with gastric cancer incidence rate variability in Costa Rican regions. J Gastroenterol. 2006; 41:632-7. [PubMed: 16932999]

9. Miwa H, Go MF, Sato N. H. pylori and gastric cancer: the Asian enigma. Am J Gastroenterol. 2002; 97:1106-12. [PubMed: 12014714]

10. Schistosomes, liver flukes and Helicobacter pylori. IARC; 1994. IARC Monographs on the Evaluation of Carcinogenic Risks to Humans; p. 177-240.

11. Correa P, Haenszel W, Cuello C, et al. A model for gastric cancer epidemiology. Lancet. 1975; 2:58-60. [PubMed: 49653]

12. Achtman M, Azuma T, Berg DE, et al. Recombination and clonal groupings within Helicobacter pylori from different geographical regions. Mol Microbiol. 1999; 32:459-70. [PubMed: 10320570]

13. Blaser MJ, Perez-Perez GI, Kleanthous H, et al. Infection with Helicobacter pylori strains possessing cagA is associated with an increased risk of developing adenocarcinoma of the stomach. Cancer Res. 1995; 55:2111-5. [PubMed: 7743510]

14. Covacci A, Censini S, Bugnoli M, et al. Molecular characterization of the 128-kDa immunodominant antigen of Helicobacter pylori associated with cytotoxicity and duodenal ulcer. Proc Natl Acad Sci U S A. 1993; 90:5791-5. [PubMed: 8516329]

15. Covacci A, Telford JL, Del Giudice G, Parsonnet J, Rappuoli R. Helicobacter pylori virulence and genetic geography. Science. 1999; 284:1328-33. [PubMed: 10334982]

16. Azuma T, Yamakawa A, Yamazaki S, et al. Correlation between variation of the 3 ' region of the cagA gene in Helicobacter pylori and disease outcome in Japan. J Infect Dis. 2002; 186:1621-30. [PubMed: 12447739]

17. Higashi H, Tsutsumi R, Fujita A, et al. Biological activity of the Helicobacter pylori virulence factor CagA is determined by variation in the tyrosine phosphorylation sites. Proc Natl Acad Sci U S A. 2002; 99:14428-33. [PubMed: 12391297]

18. Basso D, Zambon CF, Letley DP, et al. Clinical relevance of Helicobacter pylori cagA and vacA gene polymorphisms. Gastroenterology. 2008; 135:91-9. [PubMed: 18474244]

19. Atherton JC, Cao P, Peek RM Jr, Tummuru MK, Blaser MJ, Cover TL. Mosaicism in vacuolating cytotoxin alleles of Helicobacter pylori. Association of specific vacA types with cytotoxin production and peptic ulceration. J Biol Chem. 1995; 270:17771-7. [PubMed: 7629077]

20. Peek RM Jr, Thompson SA, Donahue JP, et al. Adherence to gastric epithelial cells induces expression of a Helicobacter pylori gene, iceA, that is associated with clinical outcome. Proc Assoc Am Physicians. 1998; 110:531-44. [PubMed: 9824536]

21. Aspholm-Hurtig M, Dailide G, Lahmann M, et al. Functional adaptation of BabA, the H. pylori ABO blood group antigen binding adhesin. Science. 2004; 305:519-22. [PubMed: 15273394]

22. Gerhard M, Lehn N, Neumayer N, et al. Clinical relevance of the Helicobacter pylori gene for blood-group antigen-binding adhesin. Proc Natl Acad Sci U S A. 1999; 96:12778-83. [PubMed: 10535999] 
23. Giannakis M, Chen SL, Karam SM, Engstrand L, Gordon JI. Helicobacter pylori evolution during progression from chronic atrophic gastritis to gastric cancer and its impact on gastric stem cells. Proc Natl Acad Sci U S A. 2008; 105:4358-63. [PubMed: 18332421]

24. Nguyen T, Brunson D, Crespi CL, Penman BW, Wishnok JS, Tannenbaum SR. DNA damage and mutation in human cells exposed to nitric oxide in vitro. Proc Natl Acad Sci U S A. 1992; 89:3030-4. [PubMed: 1557408]

25. Xu H, Chaturvedi R, Cheng Y, et al. Spermine oxidation induced by Helicobacter pylori results in apoptosis and DNA damage: implications for gastric carcinogenesis. Cancer Res. 2004; 64:85215. [PubMed: 15574757]

26. Fox JG, Beck P, Dangler CA, et al. Concurrent enteric helminth infection modulates inflammation and gastric immune responses and reduces helicobacter-induced gastric atrophy. Nat Med. 2000; 6:536-42. [PubMed: 10802709]

27. Bengmark S. Curcumin, an atoxic antioxidant and natural NFkappaB, cyclooxygenase-2, lipooxygenase, and inducible nitric oxide synthase inhibitor: a shield against acute and chronic diseases. JPEN J Parenter Enteral Nutr. 2006; 30:45-51. [PubMed: 16387899]

28. Foryst-Ludwig A, Neumann M, Schneider-Brachert W, Naumann M. Curcumin blocks NF-kappaB and the motogenic response in Helicobacter pylori-infected epithelial cells. Biochem Biophys Res Commun. 2004; 316:1065-72. [PubMed: 15044093]

29. Dorant E, van den Brandt PA, Goldbohm RA, Sturmans F. Consumption of onions and a reduced risk of stomach carcinoma. Gastroenterology. 1996; 110:12-20. [PubMed: 8536847]

30. Loh JT, Torres VJ, Cover TL. Regulation of Helicobacter pylori cagA expression in response to salt. Cancer Res. 2007; 67:4709-15. [PubMed: 17510398]

31. Camargo MC, Mera R, Correa P, et al. Interleukin-1beta and interleukin-1 receptor antagonist gene polymorphisms and gastric cancer: a meta-analysis. Cancer Epidemiol Biomarkers Prev. 2006; 15:1674-87. [PubMed: 16985030]

32. Amieva MR, El-Omar EM. Host-bacterial interactions in Helicobacter pylori infection. Gastroenterology. 2008; 134:306-23. [PubMed: 18166359]

33. Achyut BR, Ghoshal UC, Moorchung N, Mittal B. Association of Toll-like receptor-4 (Asp299Gly and Thr399Ileu) gene polymorphisms with gastritis and precancerous lesions. Hum Immunol. 2007; 68:901-7. [PubMed: 18082569]

34. Achyut BR, Ghoshal UC, Moorchung N, Mittal B. Role of cyclooxygenase-2 functional gene polymorphisms in Helicobacter pylori induced gastritis and gastric atrophy. Mol Cell Biochem. 2009; 321:103-9. [PubMed: 18825488]

35. Tripathi S, Ghoshal U, Ghoshal UC, et al. Gastric carcinogenesis: Possible role of polymorphisms of GSTM1, GSTT1, and GSTP1 genes. Scand J Gastroenterol. 2008; 43:431-9. [PubMed: 18365908]

36. Ghoshal UC, Tripathi S, Ghoshal U. The Indian enigma of frequent H. pylori infection but infrequent gastric cancer: is the magic key in Indian diet, host's genetic make up, or friendly bug? Am J Gastroenterol. 2007; 102:2113-4. [PubMed: 17727449]

37. Figueiredo C, Machado JC, Pharoah P, et al. Helicobacter pylori and interleukin 1 genotyping: an opportunity to identify high-risk individuals for gastric carcinoma. J Natl Cancer Inst. 2002; 94:1680-7. [PubMed: 12441323]

38. Kidd M, Lastovica AJ, Atherton JC, Louw JA. Heterogeneity in the Helicobacter pylori vacA and cagA genes: association with gastroduodenal disease in South Africa? Gut. 1999; 45:499-502. [PubMed: 10486355]

39. Letley DP, Lastovica A, Louw JA, Hawkey CJ, Atherton JC. Allelic diversity of the Helicobacter pylori vacuolating cytotoxin gene in South Africa: rarity of the vacA s1a genotype and natural occurrence of an s2/m1 allele. J Clin Microbiol. 1999; 37:1203-5. [PubMed: 10074554]

40. Segal I, Ally R, Mitchell H. Helicobacter pylori-an African perspective. QJM. 2001; 94:561-5. [PubMed: 11588215]

41. Singh M, Prasad KN, Yachha SK, Krishnani N. Genotypes of Helicobacter pylori in children with upper abdominal pain. J Gastroenterol Hepatol. 2003; 18:1018-23. [PubMed: 12911656] 
42. Kumar S, Dhar A, Srinivasan S, Jain S, Rattan A, Sharma MP. Antibodies to Cag A protein are not predictive of serious gastroduodenal disease in Indian patients. Indian J Gastroenterol. 1998; 17:126-8. [PubMed: 9795496]

43. Devi SM, Ahmed I, Francalacci P, et al. Ancestral European roots of Helicobacter pylori in India. BMC Genomics. 2007; 8:184. [PubMed: 17584914]

44. Correa P, Cuello C, Duque E, et al. Gastric cancer in Colombia. III. Natural history of precursor lesions. J Natl Cancer Inst. 1976; 57:1027-35. [PubMed: 1003539]

45. Llanos G, Correa P. Morbilidad por cancer en Cartagena. Antioquia Medica. 1966; 23:230-9.

46. Camargo MC, Yepez MC, Ceron C, et al. Age at acquisition of Helicobacter pylori infection: comparison of two areas with contrasting risk of gastric cancer. Helicobacter. 2004; 9:262-70. [PubMed: 15165263]

47. Whary MT, Sundina N, Bravo LE, et al. Intestinal helminthiasis in Colombian children promotes a Th2 response to Helicobacter pylori: possible implications for gastric carcinogenesis. Cancer Epidemiol Biomarkers Prev. 2005; 14:1464-9. [PubMed: 15941957]

48. MacDonald WC, Owen DA, Le N. Chronic advanced gastric cancer: clinicopathologic analysis of survival data. Hum Pathol. 2008; 39:641-9. [PubMed: 18439937] 


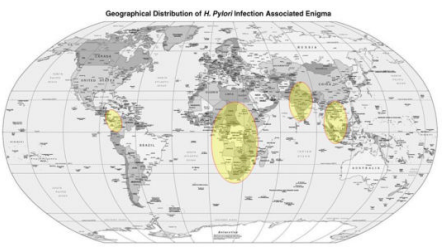

Fig. 1.

Geographical distribution of $\mathrm{H}$. pylori infection associated enigma 


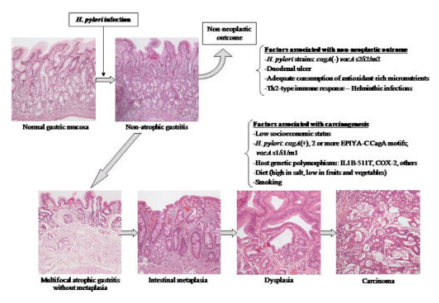

Fig. 2. 
Table 1

H. pylori genotypes. Narino, Colombia 1999 [7]

\begin{tabular}{lccl}
\hline & High-risk area $($ Pasto $) \mathbf{n = 1 3 6}$ & Low-risk area $($ Tumaco $) \mathbf{n}=\mathbf{9 1}$ & $\mathbf{P}$ \\
\hline Cag A positive $(\%)$ & 92.6 & 72.9 & 0.001 \\
Vac A s1 $(\%)$ & 93.9 & 75.5 & 0.001 \\
\hline
\end{tabular}

